than it was to those of other salts, although it was pointed out that the majority of commercial detergents consist largely of carbonates and phosphates.

An extensive survey, covering the period 1930-44, of the incidence of Mycobacterium tuberculosis and Brucella abortus in herd bulk milk from individual farms in mid- and west-Wales was reported. Some figures for school supplies of pasteurized milk, for bulk creamery skim milk, both raw and pasteurized, and for udder samples from suspected cows were also included. Reasons were advanced for the very low incidence of tubercle infection $(0.74$ per cent for 2,155 samples) in farm supplies. No tubercle bacilli were found in any of the twenty-eight samples of pasteurized milk supplied to schools, nor in the thirty-eight samples of pasteurized bulk creamery skim milk examined. Of the sixty-six samples of bulk raw creamery skim milk, 6.06 per cent contained tubercle bacilli; legislation prohibiting the return of raw by-products to farms was considered essential for the development of areas of tubercle-free herds. A much higher proportion (8.91 per cent) of raw milk samples was found to be infected with Brucella abortus, designated supplies showing a higher incidence than milk from undesignated farms. No positive results were obtained with the pasteurized samples.

In a paper dealing with the spoilage of marine fish, the sources and types of bacteria responsible were discussed. The existence in marine bacteria isolated from fish of an enzyme system, triamine-oxidase, which is not generally present in similar bacteria from other sources, was suggested as a basis for differentiating the various species of marine bacteria. The changes in flora which occurred during a 21-day period of storage on ice were also studied. Although anaerobes were not considered to be as important as aerobes in causing spoilage, the types isolated were described, and the isolation of a new serological type of non-pathogenic tetanus bacillus, Type $\mathrm{X}$, was recorded.

With the demand for canned foods for use by the Armed Forces in hot climates, new problems have had to be faced by the canning industry, since storage temperatures may be high enough to permit the germination and growth of spore-forming thermophilic organisms capable of causing spoilage. New methods of control have had to be introduced so as to reduce to a minimum the risk of infection before canning, as it is not always possible to increaise the time or temperature of sterilization sufficiently to ensure destruction of the highly resistant thermophilic spores. Difficulty in sterilizing a mixture of meat and vegetable with a relatively high fat content was thought to be due to protection of the thermophiles by the fat. Cases of spoilage in canned vegetables were rare. Difficulty in canning potatoes late in the season was thought to be associated with the use of large tubers, which had to be cut before canning, the sterilization process being inadequate to kill spores at the centre when two cut surfaces came together again.

In a paper dealing with the bacteriology of canned bacon, a novel method of canning was described. Difficulties in sterilization led to a proportion of domed cans. A gas-forming aerobic spore-former capable of utilizing nitrate as a source of oxygen, which was isolated from both spoiled and sound cans, was regarded as the causative agent, although other unknown factors were thought to play a part in the production of gas.

For several years, bacteriologists have necessarily been concerned with the more pressing practical problems; but at this meeting a refreshing change was noticeable in that a few papers of a more fundamental character were included. A much happier blend resulted, which augurs well for the future of the Society.

Proceedings of the Society, containing full abstracts of the papers read, may be purchased from the Hon. Treasurer, Mr. L. J. Meanwell, United Dairies, Ltd., Ellesmere, Salop.

\section{LONDON SCHOOL OF HYGIENE AND TROPICAL MEDICINE}

T'T was inevitable that the work of the London School of Hygiene and Tropical Medicine, which has exerted so profound an influence on the teaching and practice of tropical medicine by both British and other medical men, should have been radically affected by the War. The report of the School's work during 1943-44 shows how much its normal activities have been altered. Not only have thirty-six members of the staff been engaged on full-time war service, but also specific war problems have been studied at home, and the School has provided accommodation for members of the staff of the Medical Research Council and of the University of London, who are doing work of national importance. Nor have the School's buildings escaped war damage. Yet, during the year, it has been possible to give courses in tropical medicine to some five hundred Service medical officers and other special courses to 151 students. The acting dean, Prof. M. Greenwood, and the whole School are to be congratulated upon the year's work. It is gratifying to know that it has been possible to do, as well as war work, some fundamental research of a kind which is vital to the very existence of science, yet is, in the words of Prof. Greenwood, "slighted in wartime because the results may not be of immediate technological importance".

Prof. Greenwood refers to the difficulties which the School will have to face after the War, and he doubts whether national post-war needs will allow the School to resume normal teaching until, at the most optimistic estimate, the autumn of $1945-46$, perhaps not until a year later. He suggests that the resumption of teaching will not be easy, for the returning staff will have lost touch with the normal problems of academic work and will have to teach a generation trained somewhat hurriedly and under difficulties.

The brief departmental reports indicate the effects of departures of staff for war work and also of the national value of the work which has been accomplished in spite of these losses. Thus the Department of Entomology has been much concerned with work on D.D.T., which was originally brought to the School by a representative of the Swiss firm which placed this remarkable insecticide at the disposal of the British and American Governments (see Nature, Nov. 11, 1944, p. 600). Methods of impregnating clothing with D.D.T. for the control of human lice were devised, and this method of applying D.D.T. is now general. The use of D.D.T. for the control of the bedbug is also being studied. Much work has been done on fumigants and mosquito sprays, and a formula for the latter containing D.D.T. has been generally adopted. The physical and chemical problems involved in the control of insects by means of sprays are also being investigated. This Depart- 
ment has lost the services of Dr. V. B. Wigglesworth, who has been appointed director of the Insect Physiology Unit of the Agricultural Research Council ; but co-operation between these two departments continues. Dr. Wigglesworth has studied the part played by waxes in maintaining the impermeability of the insect cuticle to water and has found that some chemically inert dusts abrade the wax and thus kill insects by causing them to dry up (see Nature, 153, 493 ; 154, 333 (1944) ). His Unit is also studying the action of insecticides used as sheep dips against the sheep tick, Ixodes ricinus, the water relations of this tick and the physiology of the sheep blowfly, Lucilia sericata. Field trials of D.D.T. as a sheep dip are also being made. The possible importance of work of this kind to all those who are concerned with world supplies of meat, wool and other animal products can scarcely be over-estimated.

The head of the Department of Biochemistry, Prof. H. Raistrick, has given much time to work with penicillin; he is honorary scientific adviser to the Ministry of Supply on penicillin production. This Department has also studied the deterioration of service equipment in the tropics due to the action of moulds and is searching for antibiotic substances of microbiological origin. Although patulin, prepared by the Department from Penicillium patulum, proved unable to control the common cold (see Nature, 154, 807 , Dec. 30, 1944), two other metabolic products of this mould have been isolated, namely, gentisic acid and the hitherto unknown gentisyl alcohol ; the latter has been synthesized. A new antibacterial substance has been isolated from cultures of "a somewhat rare mould" which has not yet been identified with certainty; this substance appears to belong to a new type of organic compounds and its properties are being studied. Diplococcin, a new antibacterial substance formed by some strains of milk streptococci, has been isolated. It is probably, the report says, identical with a substance independently isolated at the National Dairy Research Institute, Shinfield, and described by A. T. R. Mattick and A. Hirsch (Nature, 154, 551, Oct. 28, 1944). Mattick and Hirsch found that the substance isolated by them protects mice against strains of hæmolytic streptococei virulent to mice and suggest that it may be useful for the treatment of bovine mastitis.

The appointment of Prof. J. M. Macintosh to the University of London chair of public health assures the School of vigorous and able leadership. The Association of Industrial Medical Officers is using the School more and more as its headquarters. Among researches done at the School's Department of Industrial Physiology are those on the insulating properties of clothing materials, the important question of portable sources of light, such as reading lamps, the results of which study have been published in the Transactions of the Illuminating Engineering Society, and the dangers to health of industrial dusts; advice given on the working conditions in factories has brought benefit to many workers.

The Library of the School has been busier than ever. It has increased its stock of books and pamphlets, but has experienced the difficulty of obtaining American books which is the subject of an Annotation in the Lancet $(217$, Feb. 17, 1945). The School also houses the Bureau of Hygiene and Tropical Diseases, the painstaking and indefatigable work of which, published in the pages of the Tropical Diseases Bulletin, the Bulletin of Hygiene and the Bulletin of War Medicine, makes available abstracts of the medical literature of every country in the world. These abstracts are done by a panel of experts, whose experience adds a critical quality which is absent from many other publications of this kind.

The Institute of Agricultural Parasitology, directed by Prof. R. T. Leiper, professor of helminthology in the School, has done much work at Winches Farm, St. Albans, on the nematode parasites of valuable crops. A catalogue of more than six hundred species of helminths parasitic in birds of economic importance has also been compiled. A method has been devised for the identification of certain nematode species from the females alone, which should be of great value to parasitologists ; and the nature and development of cestode hooks has been studied. It is at Winches Farm also that the work of that other invaluable source of information, the Imperial Bureau of Agricultural Parasitology, is done.

Everyone will wish the School a speedy return to its normal activities when the completion of its war work makes this possible.

\section{RACIAL PROBLEMS IN AUSTRALIA}

$\mathrm{W}$ ITH the progress of civilization and the continued penetration by the white man into the domain of the coloured peoples, there comes the problem, ever increasing in intensity, of the contact and clash of conflicting customs. Men in the stone or iron age are caught up into the complicated machinery of the Western world, and the results are necessarily difficult to regulate and often disastrous to the simpler peoples.

The Anthropological Society of South Australia at its meeting in May 1944 held a conference arranged by the South Australian Division of the Australian Association of Scientific Workers, during which there was a discussion on racial problems to which Prof. J. B. Cleland contributed a valuable address. $\mathrm{He}$ pointed out that the Australian aborigines, contrary to popular belief, present a high order of intelligence, and had they not settled in a country which provided very few amenities, they would probably by now have reached a much higher stage of civilization. But what could they do in a country boasting no animal life higher than the marsupial and practically no cultivable plants? They were forced to remain nomads and with the arid conditions so frequently obtaining could make no permanent habitations.

Potentially, however, judging by a complex language and by the attainments of certain individuals, the Australian aborigine has a mental make-up not appreciably below that of the white man, though he has specialized in a different direction. There is nothing to show that erosses between them and good. class whites are likely to produce undesirable halfbreeds; the fact that many half-castes are inferior being probably due to the low-class and often vicious white men of whom they are the offspring.

There have always been attempts to guide the aborigines into European ways, but these have here. tofore led to rapid decline and death, owing in great part to lack of interest in living when removed from their native mode of life with its frequent ceremonies. It seems, in fact, impossible for the full bloods to maintain themselves in a white community, and the only hope for them is to make the few places they can call their own as inaccessible as possible to the white man. There will naturally always be certain 